\title{
VISUALISATION OF MICROGLIA WITH THE USE OF IMMUNOHISTOCHEMICAL DOUBLE STAINING METHOD FOR CD-68 AND Iba-1 OF CEREBRAL TISSUE SAMPLES IN CASES OF BRAIN CONTUSIONS
}

\author{
Aleksandar Stankov' ${ }^{1}$ Viktorija Belakaposka-Srpanova1, Natasa Bitoljanu' ${ }^{\mathbf{1}}$, Ljupco Cakar ${ }^{\mathbf{1}}$, \\ Zdravko Cakar' ${ }^{1}$, Gorazd Rosoklija ${ }^{2,3,4}$ \\ ${ }^{1}$ Institute for forensic medicine, criminalistic and medical deontology, Medical faculty Skopje, R. Macedonia \\ ${ }^{2}$ Department of Psychiatry, Columbia University, New York, NY, USA \\ ${ }^{3}$ Division of Molecular Imaging and Neuropathology and New York State Psychiatric Institute, New York, \\ NY, USA \\ ${ }^{4}$ Macedonian Academy of Sciences \& Arts, Skopje. R. Macedonia
}

Corresponding Author: Aleksandar Stankov, Institute for forensic medicine, criminalistic and medical deontology, St Majka Tereza 17, 1000 Skopje, R. Macedonia; Tel +389 (0)2 754905 45; E-mail: astankov@ medf.ukim.edu.mk

\begin{abstract}
In the recent years it has been confirmed that the main component of the immune response in an injury of the nerve cell comes from microglia and macrophages. The main challenge in the field of microglia research is to detect the different stages of cellular activation by visualization of the cell morphology. The existing visualization techniques are based on surface molecules expression in resting and activated microglia cells. For visualization of the microglial cells and their functional state we used double labeling method for cd-68 and iba1 in brain contusions with different survival time. Microglia are stained brown with Iba-1, whereas microglia impregnated with black, grainy color, represents activated microglia stained with CD 68 . We had significantly positive results, and we were able to observe changes in the morphology of the microglia that correlated with the survival time. Using double labeling with Iba-1 and cd68 we were able to determine their physiological state based on the morphology and immunoreactivity.
\end{abstract}

Key words: microglia cells, immunohistochemistry, brain contusions

\section{Introduction}

In the last years it has been confirmed that the main component of the immune response in an injury of the nerve cell comes from the microglia and the macrophages [1]. The microglia term was introduced in the 1920 by the Spanish neuroscientist Pio del Rio Hortega, who performed the first detailed microscopic analysis of these newly discovered cells [2-4]. The original findings of these cells were vague, because of the lack of interest for their study. Microglia constitutes 5-20\% of the total number of glia cells in the CNS [5]. Microglia are ontogenetically related with the monocytic cell lineage and they inhabit the CNS during its fetal development $[6,7]$. During the embryogenesis the hematopoietic monocytes inhabit the $\mathrm{CNS}$, the cerebrospinal fluid, and the perivascular spaces in order to mature along with the cerebral tissue into typical branched resident microglia [8].

In a normal physiological state, microglia are described as cells with small cellular body and numerous long branching processes. They are very motile cells distributed throughout the cerebral tissue, constantly surveying the tissue homeostasis [9]. They respond quickly and dramatically to any pathological noxa and are 
responsible for the cleanup of dead tissue and toxic substances in order to establish tissue homeostasis in the CNS [10].

The main challenge in the field of microglia research is to detect the different states of cellular activation by visualization of cell morphology. The existing visualization techniques are based on surface molecules expression in resting and activated microglia cells. The expression of these molecules is constant, regardless the cellular state, however the regulation of their expression is different depending on the phase of activation of the cell it is in [11].

Ionized calcium binding adaptor molecule 1 [Iba1] is a 17 - $\mathrm{kDa} \mathrm{EF}$ - hand protein whose expression is restricted to microglia/macrophages [12]. Expression of Iba1 is up-regulated in activated microglia following facial nerve axotomy [13], ischemia [14], and several brain diseases $[15,16]$, thereby implicating it in the activated phenotypes of microglia. Iba 1 shares active locus with $\mathrm{F}$ - actin [filamentous actin] on membrane ruffles induced by macrophage colony - stimulating factor [M-CSF] and in phagocytic cups formed during zymosan uptake by microglia [17]. It is the key molecule in membrane ruffling and phagocytosis in to be involved in the signaling pathways of calcium and Rho family small GTPase, Rac [17], which is the essential molecule in regulating actin reorganization in membrane ruffling [18-20].

The CD68 molecule is a $110 \mathrm{kD}$ intracellular glycoprotein primarily associated with cytoplasmic granules and to a lesser extent the membranes of macrophages. The markers to the CD68 antigen are most frequently used for the identification of macrophages in immunohistochemistry. However, CD68 is also found in monocytes, neutrophils, basophils and large lymphocytes. The lisosomal protein CD68 can be used for microglial staining [21, 22]. High levels of CD68 expression are associated with macrophages and activated microglia, whilst low levels of expression are associated with resting, ramified microglia [21-23].

\section{Materials and methods}

We stained contusions of the cerebral cortex incurred by blunt force trauma in cases with no more than 30 min survival time, no more than 12 hours survival time, and with survival time of 96 hours, survival time of 144 hours, and survival time of 648 hours. We also stained control tissues without cerebral trauma obtained from subjects where the cause of death is not related to trauma or disease of the CNS. The research will not include cases with postmortem interval longer than 24 hours and cases where the cerebral injury is incurred with the use of firearms or with the use of sharp force [incising or stabbing]. The cerebral tissue we received from the autopsies performed at the Institute for Forensic Medicine, Criminalistics, and Medical Deontology, School of Medicine, University Ss. Cyril and Methodius, Skopje, R. Macedonia. Brains were processed after a signed consent from the next of keen of the deceased. The research was approved by the Ethics committee of the School of Medicine, Skopje.

The immunohistochemical staining was performed on a short time fixed human tissue with the use of $\mathrm{ABC}$ [Avidin Biotin Complex] method and double labeling for CD-68 [KP 1, Dako] with Nikel sulphat and for Iba-1 [Vako] with DAB [Diaminobenzidine] [24]. Iba-1 appeared brown, and CD 68 appeared black. Microglia are defined with Iba1 staining, whereas the microglia that was with black, grainy coloration, showed immunoreactivity for CD 68, and was differentiated as activated microglia. The 40 micron thick tissue slices were dehydrated at $60^{\circ} \mathrm{C}$, deparaffinized and rehydrated in a series of xylene and graded ethanol [100\%, 95\%, $75 \%, 50 \%$, distilled water]. Following rinsing in $\mathrm{ddH}_{2} \mathrm{O}$ and blocking of endogenous peroxidase with $0,3 \% \mathrm{H}_{2} \mathrm{O}_{2}$, heat induced epitope retrieval was applied. The sections were submersed in Tris/EDTA and heated in a microwave at $100 \%$ power. The permeabilization was facilitated with tissue exposure to buffer with $0,3 \%$ Triton $\times 100$. The sections were blocked in $3 \%$ normal horse serum [NHS], or a serum from the species used for the preparation of the secondary biotinylated antibody, for 30 minutes. The primary antibody, CD $681: 500$ in a buffer with $3 \%$ normal serum, was applied during 24 hours, at $+4^{\circ} \mathrm{C}$ on a tissue culture shaker platform, so that the tissue was constantly exposed to fresh antibodies. After rinsing, the tissue was incubated for one hour at room temperature with a byotinylated seconddary antibody directed towards the species in which the primary antibody was prepared, in a concentration of $1: 200$. The Avidin Biotin Complex was applied in $1: 100$ dilution at room temperature, for 
one hour. After washing followed visualization with DAB and Nickel. The stained tissue was washed and the staining procedure was repeated with the application of Iba 1 in a concentration of $1: 2000$, for 24 hours. After the washing, the immunohistochemical reaction was visualized using 3,3'-diaminobenzidine [DAB] without Nikel, the sections were dehydrated through graded ethanol, cleared in xylene, and cover slipped using "Permaunt" mounting medium.

The detection of the morphological changes of thr identified microglia was performed on photography of the stained microscopic slides made on Leica 5000MB microscope using $60 \mathrm{x}$ oil lens and Visiopharm software.

\section{Results}

Iba 1 is a protein whose expression is strictly bound to microglia and macrophages [12]. In our study staining with this antibody fully confirmed the results of the previous studies. The expression of this antigen (light brownbrown) was excellent in all of the stained sections. The cellular body and the processes were clearly defined from the surrounding. Using double staining, (Iba-1 and CD-68) we managed to detect microglia in which there is activation. In those cells, the intensity of the reaction of antibody - cd68 protein increased depending on the time interval. The control cases (Fig. 1) and the cases with survival time of less than 24 hours (Fig. 2), the intensity of cd68 staining was minimal, visible as few black granules in the cell. Unlike them the intensity of staining in cases with longer survival time was drastically different and the cells were completely stained with the CD-68 (Fig. 3, 4).

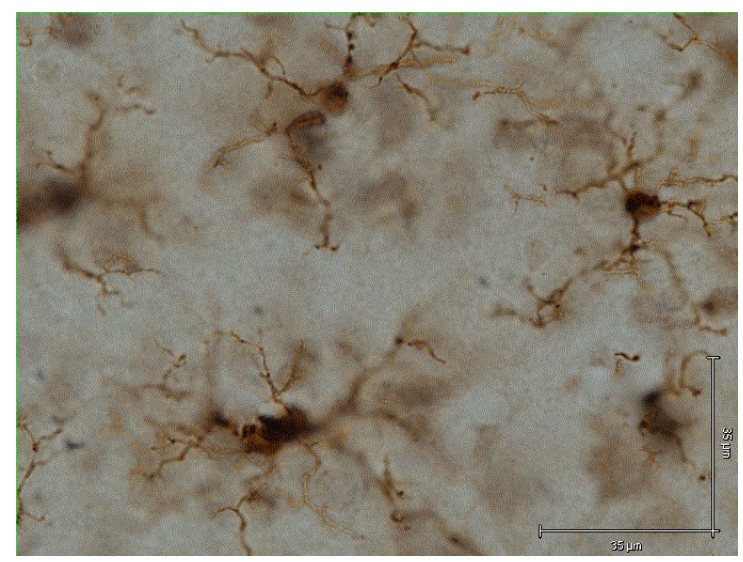

Figure 1 - Control case without any pathological stimulus. Iba-1 stain is brown show dentritic morphology of cells without CD-68 stain

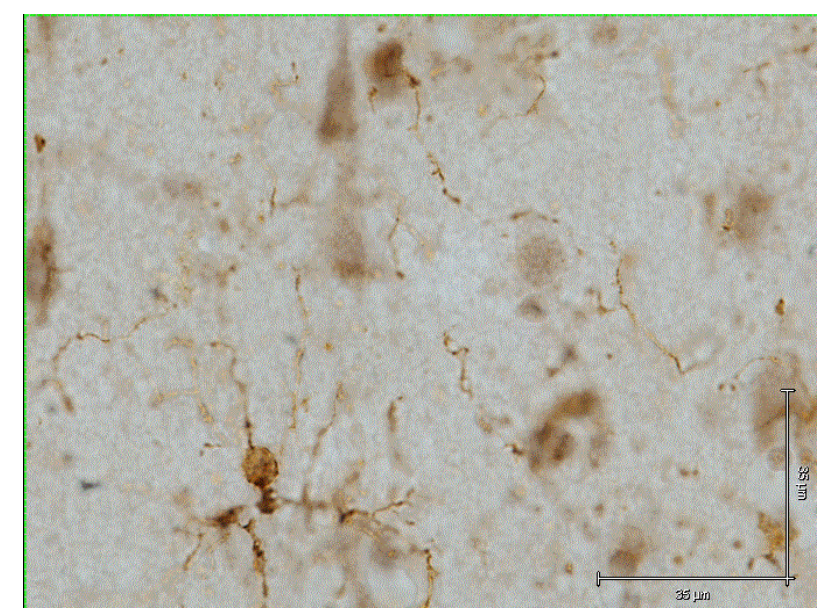

Figure 2 - Case with survival time $<24$ with cerebral contusions.Iba-1 stain is brown show dentritic morphology of cells without CD-68 stain

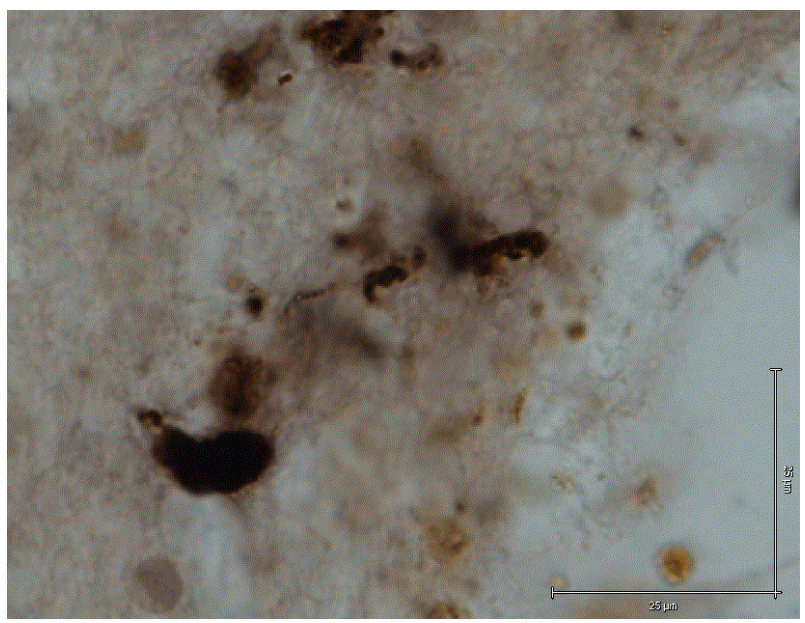

Figure 3 - Case with survival time $96 \mathrm{~h}$ with cerebral contusions. CD-68 (black), Iba-1(brown)

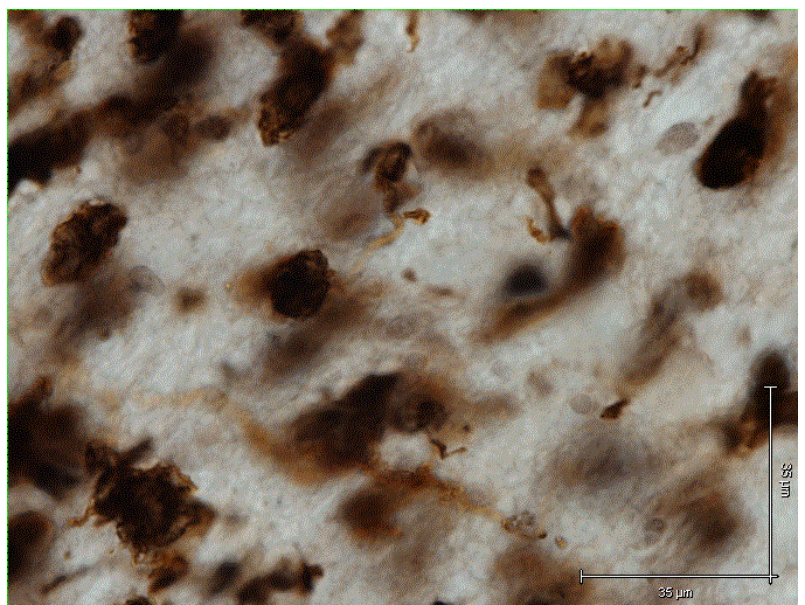

Figure 4 - Case with survival time $648 \mathrm{~h}$ with cerebral contusions. CD-68 (black), Iba-1(brown)

\section{Discusion}

Immunohistochemistry is a technique based on the antigen - antibody reaction, that is detecting expression of a certain protein in the 
cell by using specific antibody. The use of immunohistochemistry for detection and determination of the functional stadium of microglia is widespread. Microglia show great antigenic heterogeneity [25-30]. The cells from the monocyte lineage show expression of the Iba- 1 protein. Some of the preliminary studies proved that the spleen macrophages and Kupffer cells showed positive Iba-1 staining. These findings showed that Iba-1 staining can be used for identifycation of cells from the monocyt-macrophages lineage including the microglia [31].

Numerous studies showed that the lisosomal cd68 protein can be used for microglial staining $[21,22]$. Wherein the strong expression of this protein is associated with the activated microglia and macrophages, and the low expression is generally associated with resting microglia [21-23].

Using previous experiences associated with immunohistochemical staining with the use of antibodies for determination of the Iba-1and cd68 proteins we used double staining of cerebral tissue from individuals with brain contusions and individuals with no traumatic or pathological injury of the brain. With the use of double staining method with Iba-1 and cd68 we managed to determine their physiological state based on their morphology and based on the expression of the cd68 protein.

\section{REFERENCES}

1. Perry VH, Andersson PB, Gordon S. Macrophages and inflammation in the central nervous system. Trends Neurosci. 1993; 16: 268-273.

2. Perry VH, Gordon S. Microglia and macrophages In Immunology of the nervous system: Keane RW, Hickey WF (eds). Oxford University Press, New York, 1997; pp 155-182.

3. Somjen GG. Notes on the history of the concept of neuroglia. Glia.1988; 1: 2-9.

4. Streit WJ, Kincaid-Colton CA. The brain's immune system. Sci Am. 1995; 273: 54-61.

5. Kreutzberg GW. Microglia: a sensor for pathological events in the CNS. Trends Neurosci. 1996; 19(8): 312-318.

6. Oehmichen M. Functional properties of microglia. In Recent advances in neuropathology, vol. 2. Smith WT, Cavanagh JB, eds. Churchill Livingstone, Edinburgh, London, New York. 1982; pp 83-107.

7. Oehmichen M. Cytokinetic studies on the origin of the cells of the cerebrospinal fluid. J Neurol Sci. 1974; 22: $165-176$.

8. Ling EA, Wong WC. The origin and nature of ramified and amoeboid microglia: a historical review and current concepts. Glia. 1993; 7: 9-18.
9. Nimmerjahn A, Kirchhoff F, Helmchen F. Resting Microglial Cells Are Highly Dynamic Surveillants of Brain Parenchyma in Vivo. Science. 2005; [308]5726: 1314-1318.

10. Hanisch UK, Kettenmann H. Microglia: active sensor and versatile effector cells in the normal and pathologic brain. Nat Neurosci. 2007 Nov; 10[11]: 1387-94. http://dx.doi.org/10.1155/2013/205431

11. Imai Y, Ibata I, Ito D, Ohsawa K, Kohsaka S. A novel gene ibal in the major histocompatibility complex class III region encoding an EF hand protein expressed in a monocytic lineage. Biochem. Biophys. Res. Commun. 1996; 224: 855-862.

12. Ito D, Imai Y, Ohsawa K, Nakajima K, Fukuuchi Y, Kohsaka S. Microglia-specific localisation of a novel calcium binding protein, Iba1. Brain Res. Mol. Brain Res. 1998; 57: 1-9.

13. Ito D, Tanaka K, Suzuki S, Dembo T, Fukuuchi Y. Enhanced expression of Iba1, ionized calcium-binding adapter molecule 1 , after transient focal cerebral ischemia in rat brain. Stroke. 2001; 32: 1208-1215.

14. Mori I, Imai Y, Kohsaka S, Kimura Y. Upregulated expression of. Iba1 molecules in the central nervous system of mice in response to neurovirulent influenza A virus infection.Microbiol. Immunol. 2000; 44: 729-735.

15. von Ertzen. U, Egensperger R, Kosel S, Grasbon-Frodal EM, Imai Y, Bise K, et al. Microglia and the development of spongiform change in Creutzfeldt-Jakob disease. J Neuropathol. Exp. Neurol. 1998; 57: 246-256.

16. Ohsawa K, Imai Y, Kanazawa H, Sasaki Y, Kohsaka $\mathrm{S}$. Involvement of Iba1 in membrane ruffling and phagocytosis of macrophages/microglia. J. Cell Sci. 2000; 113: 3073-3084.

17. Ridley AJ, Paterson HF, Johnston CL, Diekmann D, Hall A. The small GTP-binding protein rac regulates growth factorinduced membrane ruffling. Cell. 1992; 70: 401-410.

18. Hall A. Rho GTPases and the actin cytoskeleton. Science. 1998; 279: 509-514.

19. Allen WE, Jones GE, Pollard JW, Ridley AJ. Rho, Rac and $\mathrm{Cdc} 42$ regulate actin organization and cell adhesion in macrophages. J. Cell Sci. 1997; 110: 707-720.

20. Graeber MB, Streit WJ, Kiefer R, Schoen SW, Kreutzberg GW. New expression of myelomonocytic antigens by microglia and perivascular cells following lethal motor neurone injury. J. Neuroimmunol. 1990; 27: 121-131.

21. Slepko N, Levi G. Progressive activation of adult microglial cells in vitro. Glia 1996; 16: 241-246.

22. Kingham PJ, Cuzner ML, Pocock JM. Apoptotic pathways mobilized in microglia and neurones as a consequence of chromogranin A-induced microglial activation. J. Neurochem. 1999; 73: 538-547.

23. Schnieder TP, Trencevska I, Rosoklija G, Stankov A, Mann JJ, Smiley J, Dwork AJ. Microglia of prefrontal white matter in suicide. J Neuropathol Exp Neurol. 2014 Sep; 73(9): 880-90.

24. Gehrmann J, Kreutzberg GW. Characterisation of two new mono-clonal antibodies directed against rat microglia, J. Comp. Neurol. 1991; 313: 409-430.

25. Graeber MB, Streit WJ, Kreutzberg GW. Axotomy of the rat facial nerve leads to increased CR3 complement receptor expression by activated microglial cells, J. Neurosci. Res. 1988; 211: 8-24. 
26. Graeber MB, Streit WJ, Kreutzberg GW. Identity of ED2-positive perivascular cells in rat brain, J. Neurosci. Res. 1989; 22: 103-106.

27. Lawson LJ, Perry VH, Dri P, Gordon S. Heterogeneity in the distribution and morphology of microglia in the normal, adult mouse brain, Neuroscience. 1990; 39: 151-170.

28. Perry VH, Hume DA, Gordon S. Immunohistochemical localisation of macrophages and microglia in the adult and developing mouse brain, Neuroscience. 1985; 15: 313-326.

29. Thomas WE. Brain macrophages: evaluation of microglia and their functions, Brain Res. Rev. 1992; 17: 61-74.

30. Ito D1, Imai Y, Ohsawa K, Nakajima K, Fukuuchi Y, Kohsaka S. Microglia-specific localisation of a novel calcium binding protein, Iba1Brain Res Mol Brain Res. 1998; 57[1]: 1-9.
Резиме

\section{ВИЗУАЛИЗАЦИЈА НА МИКРОГЛИЈА КЛЕТКИ СО УПОТРЕБА НА ИМУНОХИСТОХЕМИСКО ДВОЈНО БОЕЫЕ ЗА СD-68 И Іba-1 НА ПРИМЕРОЦИ ОД МОЗОЧНО ТКИВО КАЈ СЛУЧАИ СО МОЗОЧНИ НАГМЕЧУВАЫА}

Александар Станков ${ }^{1}$, Викторија БелакапоскаСрпанова ${ }^{1}$, Наташа Битољану ${ }^{1}$, Љупчо Чакар ${ }^{1}$, Здравко Чакар ${ }^{1}$, Горазд Росоклија ${ }^{2,3,4}$

${ }^{1}$ Институт за судска медицина, криминалистика и медицинска деонтологија,

Медицински факултет, Скопје, Р. Македонија

2 Оддел за психијатрија, Универзитет Колумбија, Њујорк, САД

${ }^{3}$ Оддел за молекуларен имиџинг

и невропатологија, Државен психијатриски институт, Њујорк, САД

${ }^{4}$ Македонска академија на науките

и уметностите, Скопје, Р. Македонија

Во изминатите години е потврдено дека главната компонента на имуниот одговор при повреда на нервните клетки доаѓа од микроглија клетките и макрофагите. Главниот предизвик во микроглијалните истражувања е да се детерминираат различните стадиуми на клеточната активација со визуелизација на нивната морфологиjа. Постоечките техники за визуелизација се базирани на експресијата на површинските молекули кај мирувачките и активираните микроглија клетки. Во нашето истражување за визуелизација на микроглија клетките користевме метода на двојно боење за ЦД-68 и ИБА-1 на краткотрајно фиксирано мозочно ткиво. Примероците беа земени од поединци кај кои постојат нагмечувања на кората од мозокот и кои се со различно време на преживување. Со употреба на оваа имунохистохемиска метода успеавме да ги визуелизираме микроглија клетките и врз основа на нивната морфологија и експресијата на ЦД68 антигените да ја одредиме нивната физиолошка состојба која се менуваше во зависност од времето на преживување.

Клучни зборови: микроглија клетки, имунохистохемија, мозочни нагмечувања. 